\title{
NEEM (AZADIRACHTAINDICA) AND ITS POTENTIAL FOR SAFEGUARDING HEALTH, PREVENTION AND TREATMENT OF DISEASES
}

\author{
Munazza Shareef, Muhammad Sohail Akhtar \\ Institute of Pharmacy, Physiology and Pharmacology Faculty of Veterinary Sciences University of Agriculture, Faisalabad \\ University of Health Sciences, Lahore. \\ *Corresponding Author's E-mail: Munazzashareef76@gmail.com
}

This is an open access article distributed under the Creative Commons Attribution License, which permits unrestricted use, distribution, and reproduction in any medium, provided the original work is properly cited.

\section{ARTICLE DETAILS}

Article History:

Received 12 November 2017 Accepted 12 December 2017 Available online 1 January 2018

\section{ABSTRACT}

Neem (Azadirachtaindica) is belong to family Meliaceae and it is it is rich source of antioxidant. It has been widely used in medicines of Chinese, Ayurvedic, and Unani prescriptions overall particularly in Indian Subcontinent in the treatment and counteractive action of different maladies. From various parts of neem, 140 different mixtures can be made. All parts of the neem tree-leaves, blossoms, seeds, organic products, roots and bark have been utilized customarily for the treatment of aggravation, contaminations, fever, skin ailments and dental issue. The therapeutic utilities have been portrayed particularly for neem leaf. Neem leaf and its constituents have been shown to display immunomodulatory, calming, antihyperglycaemic, antiulcer, antimalarial, antifungal, antibacterial, antiviral, cell reinforcement, antimutagenic and anticarcinogenic properties. This survey abridges the extensive variety of pharmacological uses of neem leaf.

\section{KEYWORDS}

Azadirachtaindica, Antimicrobial activity, Antimutagenic, Anticarcinigenic, Antioxidant.

\section{INTRODUCTION}

The Screening of plants with medicinal properties is performed for the bioactive substances or compounds. These bioactive compounds give a way forward for the development of less expensive agents with antimicrobial properties. The drug resistance against number of microorganisms is a serious global problem. This drug resistance has become a challenge for the pharmaceutical industry and the clinicians. As the herbal drugs are rich source of the therapeutic compounds. Therefore, the use of herbal drugs is continuously rising in the developed countries. Based on a study, the bioactive components of the medicinal plants form the basis in pharmaceutical lead compounds, pharmaceutical intermediates, nutraceuticals and in medicine [1].

The new antimicrobial agents are safer with high efficacy. Such as a plant named as Azadirachtaindica (neem) has antimicrobial and other therapeutic properties. Various parts, like leaves, bark and seeds of the Azadirachtaindica are shown to have antimicrobial activities. The researchers have been using different techniques such as Agar diffusion method and Micro-broth dilution methods. By using these methods minimum inhibitory concentration of Azadirachtaindica (neem) has been determined. Studies showed that the extract of the leaf has strong antimicrobial activity [2].

The antimicrobial activity of Azadirachtaindica (neem) against fungi and bacteria is tested at concentrations 500, 1000 and $2000 \mu \mathrm{g} / \mathrm{ml}$. Antimicrobial activity of seed extract was found to be least effective while bark extract exhibited the moderate activity both against bacteria and fungi. For all the tested microorganisms the Minimum Inhibitory Concentration (MIC) of bark extract is was found to be in the range of 500 to $2000 \mu \mathrm{g} / \mathrm{ml}$. Different studies have shown that the aqueous extract of leaf and bark of the Azadirachtaindica have strong antimicrobial potential. The Azadirachtaindica (A. Indica), common name is Neem [3].

It belongs to the family Meliaceae. Neem is the natural source of the many therapeutic principals. Neem has shown the antiviral activity against measles, chikungunya, coxsackie B viruses and vaccinia. It also has shown the antifungal and antibacterial activity against various pathogenic microorganisms. Neem has variety of therapeutic effects like antiulcer, anti-inflammatory, antimalarial, antimutagenic, anticarcinogenic, antioxidant and antidiabetic. These therapeutic activities of neem are due to presence of many active compounds. Study showed that they are present in bark, seed and leaves of the neem [4].

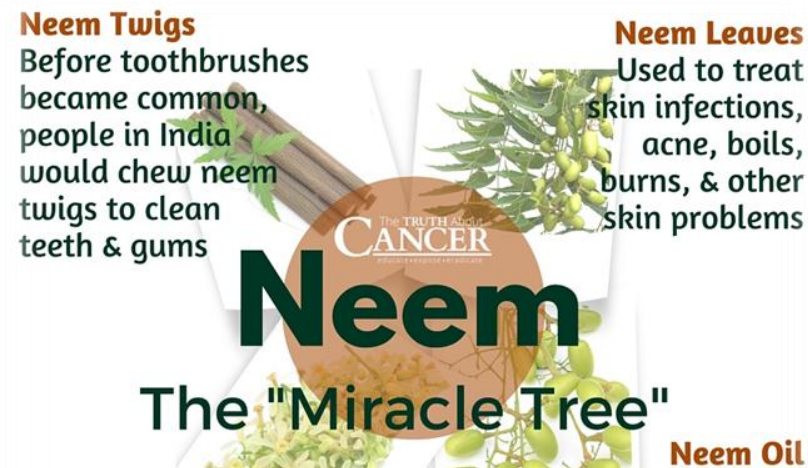

Neem Flowers

Used in aromatherapy \& medicinally to treat anorexia, nausea, and intestinal worms
Extracted from fruits and seeds. Used in cosmetics \& beauty products such as soaps, hair oil, hand wash, and soap
Figure 1: Pharmacological properties of Neem [5]

In various research studies the antimicrobial activity of neem has been investigated; however, there is no comparative study is performed on the anti-microbial effects of the leaves, bark and seeds. Their therapeutic activities depend on various factors for example thickness of the bark, inoculums size, and the uniformity of the gel. Temperature and $\mathrm{pH}$ also has 
shown effect on the accuracy and reproducibility of the Agar Diffusion method. Azadirachtaindica (Neem) is known as "Village dispensary" in India. Study showed that it is the most commonly used plant for domestic and household remedy for different ailments [5].

Table 1: Phytochemical analysis of Azadirachtaindica (Neem)

\begin{tabular}{|l|l|l|}
\hline Sr.\# & Phytochemical constituents & Extract \\
\hline 1. & Saponins & ++ \\
\hline 2. & Tannin & + \\
\hline 3. & Terpens & - \\
\hline 4. & Anthraquinone & - \\
\hline 5. & Deoxysugars & - \\
\hline 6. & Steroids & - \\
\hline 7. & Flavonoids & + \\
\hline 8. & Alkaloids & + \\
\hline 9. & Phenolic & + \\
\hline
\end{tabular}

Key (-Absent, +Present, ++Marked)

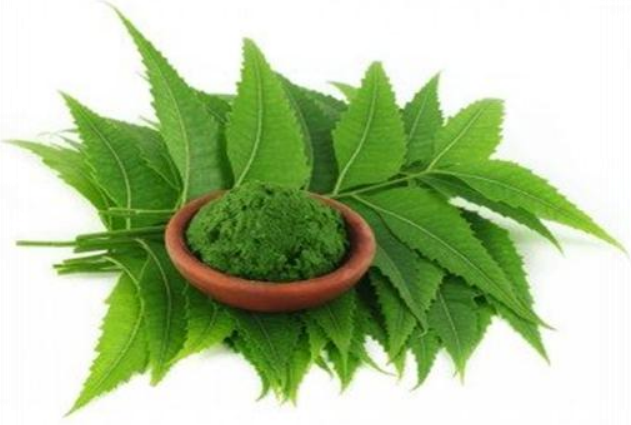

Figure 2: Neem leaves

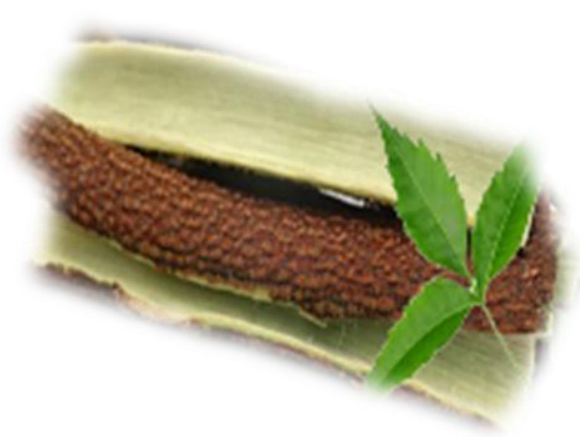

Figure 3: Neem bark

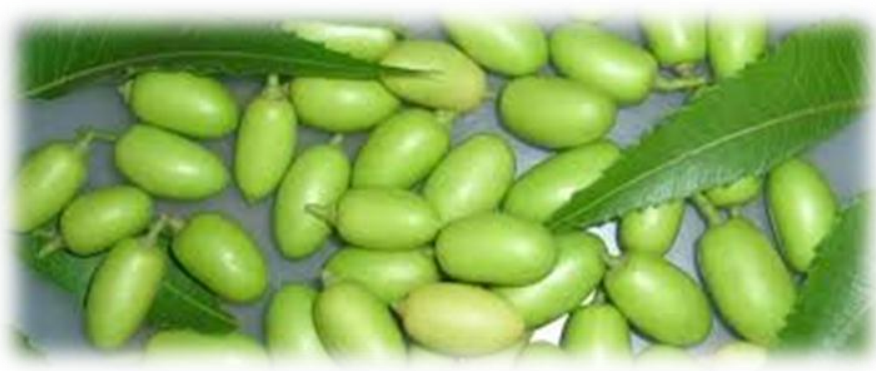

Figure 4: Neem seeds

Neem is well growing in tropical and semi-tropical areas for example: India, Bangladesh, Pakistan, and Nepal. It grows up to $20-23 \mathrm{~m}$ tall and trunk is straight and has a diameter around $4-5 \mathrm{ft}$. The leaves are compound, imparipinnate, with each comprising 5-15 leaflets. Its fruits are green in color which turn golden yellow on ripening in the months of June-August. Taxonomic position of Azadirachtaindica (neem) is classified in:

Table 2: Taxonomic position of Azadirachtaindica (neem) [6].

\begin{tabular}{|l|l|}
\hline Order & Rutales \\
\hline Suborder & Retinae \\
\hline Family & Meliaceae \\
\hline Subfamily & Melioideae \\
\hline Tribe & Melieae \\
\hline Genus & Azodirachta \\
\hline Species & Indica \\
\hline
\end{tabular}

\section{Active constituents:}

1. Azadirachtin

2. Nimbolinin

3. Nimbin

4. Nimbidin

5. Nimbidol

6. Salannin

7. Quercetin

There are many mechanisms responsible for the anti-microbial effects of neem. All the active components of neem have inhibitory effect on the bacterial growth and leads to breakdown of cell wall. The major principal constituent of neem is Azadirachtin. It is a complextetranortriterpenoidlimonoid. It is present in seeds. It is responsible for both toxic and antifeedant effects in insects. Results shows that the ethanolic extract of leaves of neem showed antibacterial activity in vitro against both Staphylococcus aureus and MRSA with large zones of inhibition observed at $100 \%$ concentration [7]

1. Due to rich source of antioxidant, Neem plays role as free radical scavenging plant. Concentration-dependent antiradical scavenging activity and reductive potential has been shown by Azadirachtin and nimbolidein the following order: nimbolide>azadirachtin>ascorbate.

2. Neem ingredient shows effective role in the management of cancer through the regulation of cell signaling pathways. Neem modulates the activity of various tumour suppressor genes (e.g., p53, pTEN), angiogenesis (VEGF), transcription factors (e.g., NF- $\kappa \mathrm{B}$ ), and apoptosis (e.g., bcl2, bax).

3. Neem also plays role as anti-inflammatory via regulation of proinflammatory enzyme activities including cyclooxygenase (COX), and lipoxygenase (LOX) enzyme [7].

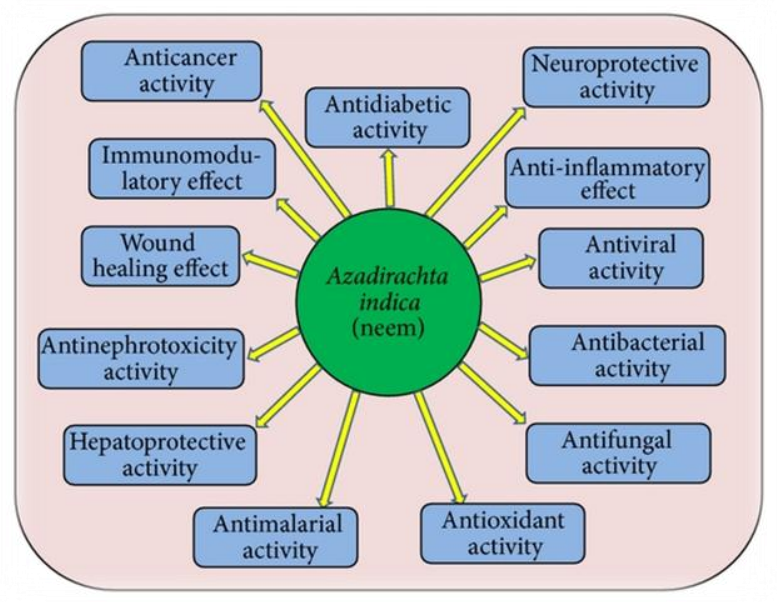

Figure 5: Different pharmacological activities of Neem

\section{ANTIBACTERIAL EFFECT OF NEEMNANO-EMULSION (NE)}

The continuous exposure of pathogenic bacteria V. vulnificus to antibiotics leads to resistance to antimicrobial agents. Hence, it's a need of time to replace the antimicrobial agents with the natural medicinal plants like neem [8]. The MIC of neem was determined against the pathogenic bacteria, V. vulnificus. The results of MIC $(150 \mu \mathrm{g} / \mathrm{mL})$ had proven the antibacterial effect of neem against the V. vulnificus. The MIC of neem was 
determined by using Sterile Disc method and Well Diffusion Method [9]. Based on a study, the well-diffusion method showed that the NE (Neem) at the concentration of $150 \mu \mathrm{g} / \mathrm{mL}$ showed a zone of inhibition of $15.3 \pm 0.5$ $\mathrm{mm}$, and no zone of inhibition was seen in the control well method [10] The comparison of antibacterial activity was performed between NEloaded sterile disc and antibiotic disc (commercially available). Study showed the NE had a zone of inhibition of $21.6 \pm 1.5 \mathrm{~mm}$ whereas the commercially available tetracycline had a zone of inhibition of $32.3 \pm 1.5$ $\mathrm{mm}[11]$.

The literature studies have shown the antibacterial effect of neemNE (Nano-emulsion) against many other pathogenic bacterias such as Aeromonassalmonicida, Klebsiellapneu-moniae, Vibrio sp., and Pseudomonas aeruginosa compared to neem oil. As the droplet size of NE is small that allows its more penetration into the cell membrane of microbes as compared to neem oil. The bacteria have thick lipid layer therefore, the thick lipid layer is susceptible to the antimicrobial compounds. According to research as Nano emulsion was prepared by using the surfactants, that cause more penetration in lipid membrane of pathogenic microbes [12].

\section{ANTIOXIDANT ACTIVITY}

The main culprits for generation of many diseases are free radical and oxygen species. Therefore, the important step in prevention of diseases is neutralization of activity of free radical. Antioxidant deactivates the reactive oxygen species/free radical. It also stabilizes the reactive oxygen species before they attack on any biological system. They activate the antioxidative enzyme. This ant oxidative enzyme prevents the damage due to reactive oxygen species and free radicals.

Azadirachtaindica (neem) have been reported to have anti-oxidant activity. The leaves, seeds, bark and oil of neem are rich source of antioxidants. A study in literature showed that in vitro antioxidant activity in different crude extracts of the leaves of Azadirachtaindica (neem) and antioxidant capacity of different crude extracts was as follows: chloroform $>$ butanol > ethyl acetate extract $>$ hexane extract $>$ methanol extract [13]. The chloroform crude extracts of neem could be used as a natural antioxidant. Other results revealed that azadirachtin and nimbolide showed concentration-dependent antiradical scavenging activity and reductive potential in the following order: nimbolide>azadirachtin $>$ ascorbate. According to a study, administration of azadirachtin and nimbolide inhibited the development of DMBAinduced HBP carcinomas through prevention of procarcinogen activation and oxidative DNA damage and upregulation of antioxidant and carcinogen detoxification enzymes [14].

\section{ANTICANCER ACTIVITY}

Worldwide cancer is major health problem. It is a multifactorial disease. The cancer progression occurs due to alteration in genetic makeup and molecular structure. In modern world the cancer is treated with chemotherapy however, chemotherapy has adverse effects on the normal cells of the body. The literature has showed that the cancer disease can be treated by various mechanism such as; inhibition of the growth of malignant cells through activation of cellular proliferation, apoptosis, tumour suppressor gene, and various other molecular pathways. Study showed flavonoids are active constituents of neem that play important role in inhibition of cancer [15].

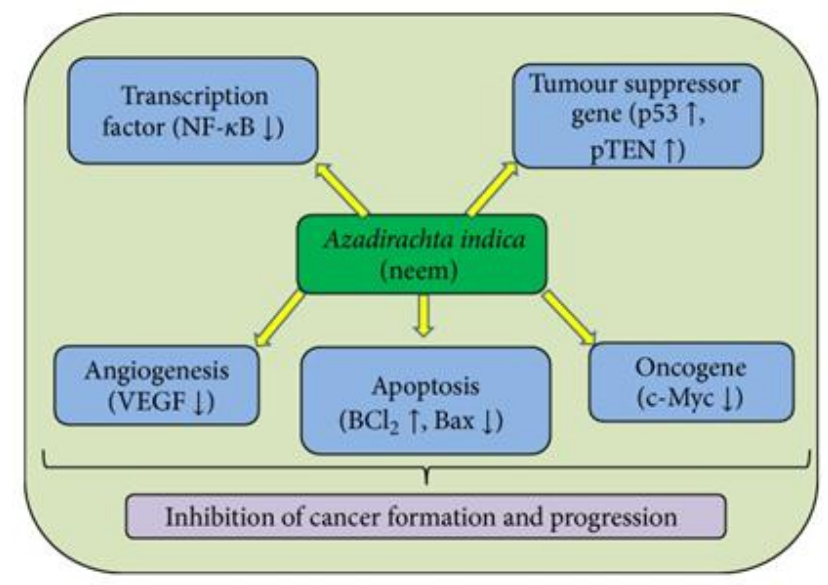

Figure 6: Anticancer activity of Azadirachtaindica (neem) through the modulation of various signals pathways [16].
Mutagenic effects of 7,12-dimethylbenz(a)anthracene has been found in neem oil. Human choriocarcinoma (BeWo) cells were used to investigate the cytotoxic effects of nimbolide. Azadirachtaindica hold various ingredients and theses constituents activate the tumor suppressor genes and inactivate the activity of several genes involved in the cancer development and progression such as VEGF, NF- $\kappa$ B, and PI3K/Akt [15] Neem has been reported to be a good activator of tumor suppressor gene and inhibitor of VEGF and phosphoinositol PI3K/Akt pathways. Based on a study, it also activates apoptosis, suppression of NF- $\kappa$ B signaling, and cyclooxygenase pathway [17].

The literature has shown the anti-proliferative property of ethanolic extract of neem leaves. This study was done with ethanolicneem leaves extract alone and in combination with cisplatin. A cell viability assay was performed on human breast (MCF-7) and cervical (HeLa) cancer cells.in order to determine the mode of cell death the cell cycle analysis and nuclear morphological examination were performed. Further, the RT-PCR technique was used to analysis the progression of cell cycle, expression of genes involved in apoptosis, and to identify its molecular targets. As compared to individual drugs, synergistic growth inhibition of these cells was observed with lower dose combinations of ethanolicneem leaves extract with cisplatin. Ethanolicneem leaves extract stimulate the expression of bax, cyclin D1, and cytochrome P450 monooxygenases (CYP 1A1 and CYP 1A2) in a time-dependent manner in these cells. As a result, it shows the chemopreventive property of neem alone and in combination with cispltin. They reduce the cytotoxic effects on normal cells. Thus, neem may be a prospective therapeutic agent to combat gynecological cancers.
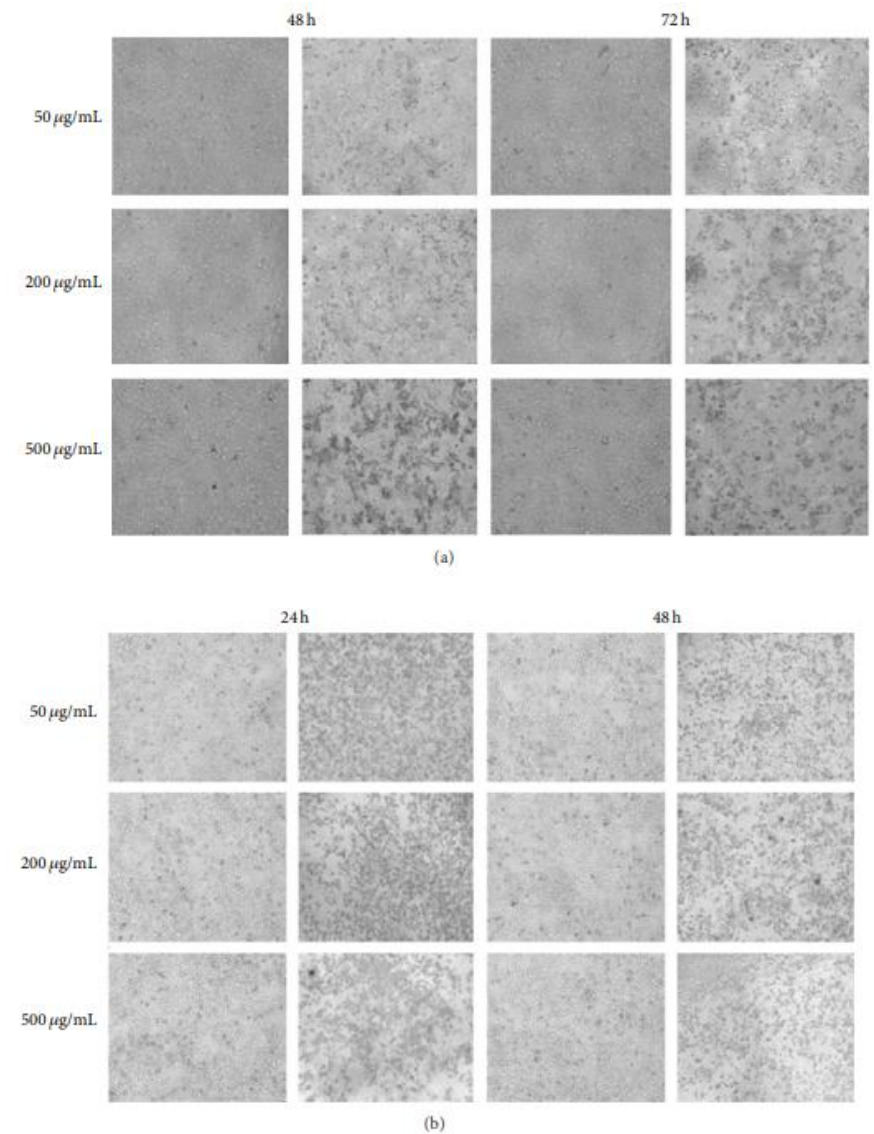

Figure 7: ENLE-induced morphological changes in MCF-7 (a) and HeLa cells (b) at varying concentrations and time-points. 50, 200, and 500 $\mu \mathrm{g} / \mathrm{mL}$ ENLE-treated (a) MCF-7 (for 48 and $72 \mathrm{~h}$ ) and (b) HeLa cells (24 and $48 \mathrm{~h}$ ) showed dose- and time-dependent increase in the morphological changes associated with cell death via apoptosis compared to the untreated cells (magnification 100x) [18].

Another study was performed to investigate the protective effect of Azadirachtaindica (neem) leaves against cisplatin side effect that is nephrotoxicity and hepatotoxicity. Neem leaves showed significant protection as evidenced by the decrease of elevated serum alanine aminotransferase, aspartate aminotransferase, gamma glutamyltranspeptidase, alkaline phosphatase, total bilirubin, creatinine, uric acid and urea. This improvement of physiological function was associated with high protection against histopathological injury induced by cisplatin on liver and kidney. These results suggest that neem leaves pre, co and post-treatment can prevent the hepato and nephrotoxicity 
induced by cisplatin [19].

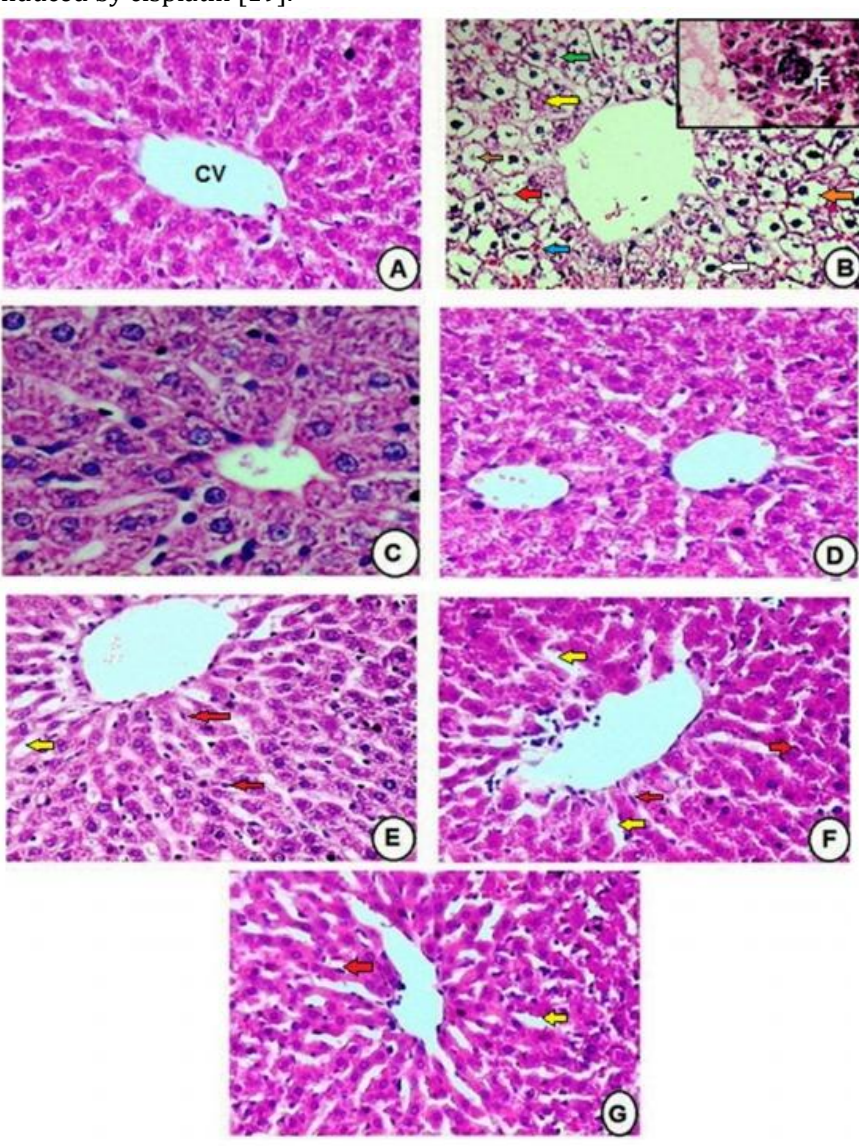

Figure 8: Neem leaves extract protects liver from cisplatin-induced injure. A; control liver section with the normal architecture of hepatic lobule. The central vein (CV) lies at the center of the lobule surrounded by cords of hepatocyte. B; rats treated with cisplatin shows loss of hepatic tissue structural pattern and hydropic degeneration ( ) in the hepatocytes, granulated cytoplasm( ), the pyknotic nuclei( ), Karyorrhexis ( ), Karyolysis ( ), pale stained nuclei ( ), congested blood sinusoid () and focal necrosis associated with lymphocytic infiltration (f). C and D; rats treated with neem leaves extract for 5 and 10 days, respectively. E, F and G; rats treated with a single dose of cisplatin followed by a daily dose of neem leaves extract for 5 days, neem leaves extract for 5 days before injection of a single dose of cisplatin and neem leaves extract for 5 days before and after injection of a single dose of cisplatin, respectively, showing the nearly normal polyhedral hepatocyte, the dilated blood sinusoids ( ) and activated Von Kupffer cell () (H \& E X 200) [19].

\subsection{Effect of Neem on Oncogene}

An oncogene is defined as a mutated gene. Oncogene have key role in the development and progression of cancers. An experiment was performed to identify the effect of leaf extract on c-Myc oncogene expression in 4T1 breast cancer BALB/c mice. The results revealed that $500 \mathrm{mg} / \mathrm{kg}$ neem leaf extract (C500) group showed significant suppression of c-Myc oncogene expression as compared to the cancer control group [20].

\subsection{Effect of Neem as Anti-Inflammatory}

There are many plants having anti-inflammatory effects. Previous study has shown that extract of neem leaves at a dose of $200 \mathrm{mg} / \mathrm{kg}$, p.o., showed significant anti-inflammatory activity in cotton pellet granuloma assay in rats. However, dexamethasone is less efficacious than the neem extract. The literature has shown that nimbidin suppresses the functions of macrophages and neutrophils relevant to inflammation [21].

\section{HEPATOPROTECTIVE EFFECT OF NEEM}

A study was performed to investigate the hepatoprotective role of azadirachtin-A in carbon tetrachloride (CCl4) induced hepatotoxicity in rats and histology and ultrastructure results confirmed that pretreatment with azadirachtin-A dose-dependently reduced hepatocellular necrosis. Furthermore, results of the study show that pretreatment with azadirachtin-A at the higher dose levels moderately restores the rat liver to normal [22].

\section{ANTIMICROBIAL EFFECT}

Based on a study, neem has important role in inhibition of bacterial growth. It is effective against number of pathogenic bacteria, fungi and viruses [23].

\subsection{Antibacterial Activity}

Herbal alternatives as endodontic irrigants were used to evaluate the antimicrobial activity and efficacy. The resulting data was compared with the standard irrigant sodium hypochlorite, and it was seen that the grape seed extract and leaf extract exhibited the zone of inhibition. It means they have antimicrobial properties. Study showed leaf extracts showed significantly greater zones of inhibition than $3 \%$ sodium hypochlorite [24].

Anther research have revealed that the neem extracts and guava have antibacterial activity against 12 strains and foodborne pathogens. The results of the study suggesting that neem extracts possess compounds containing antibacterial properties that can potentially be useful to control foodborne pathogens and spoilage organisms [25].

Another experiment was made to evaluate the anti-bacterial activity of the bark, leaf, seed, and fruit extracts of Azadirachtaindica (neem) on bacteria isolated from adult mouth and results revealed that bark and leaf extracts showed antibacterial activity against all the test bacteria used. Furthermore, seed and fruit extracts showed antibacterial activity only at higher concentrations [26].

\subsection{Antiviral Activity}

Results demonstrated that neem bark (NBE) extricate essentially blocked HSV-1 passage into cells at fixations extending from 50 to $100 \mu \mathrm{g} / \mathrm{mL}$. Besides, blocking movement of NBE was seen when the concentrate was preincubated with the infection yet not with the objective cells recommending an immediate hostile to HSV-1 property of the neem bark. Leaves concentrate of neem (Azadirachtaindica A. Juss.) (NCL-11) has demonstrated virucidal action against coxsackievirus infection B-4 as proposed by means of infection inactivation and yield decrease measure other than meddling at an early occasion of its replication cycle [27].

\subsection{Antifungal Activity}

Examination was made to assess the adequacy of different concentrates of neem leaf on seed borne fungi Aspergillus and Rhizopus and results affirmed that development of both the contagious species was fundamentally hindered and controlled with both alcoholic and water extricate. According to a study, alcoholic concentrate of neem leaf was best when contrasted with fluid concentrate for impeding the development of both parasitic species [28]. Another finding demonstrated the antimicrobial part of watery concentrates of neem cake in the hindrance of spore germination against three sporulating organisms, for example, C. lunata, $H$. pennisetti, and C. gloeosporioides f. sp.mangiferae and aftereffects of the examination uncovered that methanol and ethanol concentrate of Azadirachtaindicashowed development restraint against Aspergillusflavus, Alternariasolani, and Cladosporium [29].

Watery concentrates of different parts of neem, for example, neem oil and its central standards have antifungal exercises and have been accounted for by before agents. An examination was embraced to look at the antifungal movement of Azadirachtaindica L. against AlternariasolaniSorauer and results affirmed that ethyl acetic acid derivation division was discovered best in hindering parasitic development with MIC of $0.19 \mathrm{mg}$ and this part was likewise powerful than fungicide (metalaxyl + mancozeb) as the fungicide has MIC of $0.78 \mathrm{mg}$ [30].

\section{REFERENCES}

[1] Joshi, B., Sah, G.B., Basnet, B.B., Bhatt, M., Sharma, D., Subedi, K., 2011. Phytochemical extraction and antimicrobial properties of different medicinal plants, Ocimum Sanctum (Tulsi), Eugenia caryophyllata (clove), AchytanthesBidentata (Datiwan) and AzadirachtaIndica (Neem). Journal of Microbiology and Antimicrobial, (3), 1-7.

[2] Gupta, S.K., Prakash, J., Srivastava, S. 2001. Validation of traditional claim of Tulsi, Ocimum sanctum Linn. as a medicinal plant. Indian Journal of Experimental Biology, (40), 765-73. 
[3] Bhatt, M.K., Shankar, M.B., Saluja, A.K., Dholwani, K.K., Captain, A.D. 2012. Evaluation of antimicrobial activity of Ocimum Sanctum Methanolic extract. Journal of Pharmaceutical and Scientific Innovation, (1), 39-41.

[4] Murudkar, A., Mundhada, S.S., Tatke, P.A. 2007. Antibacterial activity of MimusopsElengi Linn. Bark against dental pathogens. Indian. Journal of Pharmaceutical Education and Research, (41), 114-20.

[5] Deshpande, R.R., Ruikar, A., Panvalkar, P.S., Ankur, K. 2010. Comparative evaluation of different concentration of MimusopsElengi (L) extract as an antimicrobial against salivary microflora. Journal of Biomedical Sciences and Research, (2), 151-4.

[6] Girish, K., Neem, S.B.S. 2008. A green treasure. Electronic Journal of Biology, 4, 102-111.

[7] Prabhat, Ajaybhan, Navneet, Chauhan, A. 2010. Evaluation of antimicrobial activity of six medicinal plants against dental pathogens. Report and Opinion (2), 37-42.

[8] Kim, J.H., Choresca, C.H., Jr, Shin, S.P., Han, J.E., Jun, J.W., Park, S.C. 2012. Occurrence and antibiotic resistance of Vibrio vulnificus in seafood and environmental waters in Korea. Journal of Food Safety, 31 (4), 518-524.

[9] Bohora, A., Hegde, V., Kokate, S. 2010. Comparison of antibacterial efficiency of neem leaf extract and 2\% sodium hypochlorite against $\mathrm{E}$. faecalis, C. Albicans and mixed culture. Endodontology, (22), 10-3.

[10] Han, F., Walker, R.D., Janes, M.E., Prinyawiwatkul, W., Ge, B. 2007. Antimicrobial susceptibilities of Vibrio parahaemolyticus and Vibrio vulnificus isolates from Louisiana Gulf and retail raw oysters. Applied and Environmental Microbiology, 73 (21), 7096-7098.

[11] Kim, J.H., Choresca, C.H., Jr, Shin, S.P., Han, J.E., Jun, J.W., Park, S.C. 2011. Occurrence and antibiotic resistance of Vibrio vulnificus in seafood and environmental waters in Korea. Journal of Food Safety, 31 (4), 518524.

[12] Taylor, E., Webster, T.J. 2011. Reducing infections through nanotechnology and nanoparticles. International Journal of Nanomedicine, (6), 1463-1473.

[13] Biswas, K., Chattopadhyay, I., Banerjee, R.K., Bandyopadhyay, U. 2002. Biological activities and medicinal properties of neem (Azadirachtaindica) Current Science, 82 (11), 1336-1345.

[14] Prashant, G.M., Chandu, G.N., Murulikrishna, K.S., Shafiulla, M.D. 2007. The effect of mango and neem extract on four organisms causing dental caries: Streptococcus mutans, Streptococcus salivavius, Streptococcus mitis, and Streptococcus sanguis: An in vitro study. Indian Journal of Dental Research, (18), 148-51.

[15] Paul, R., Prasad, M., Sah, N.K. 2011. Anticancer biology of Azadirachtaindica L (neem): a mini review. Cancer Biology and Therapy, 12 (6), 467-476.

[16] Paul, R., Prasad, M., Sah, N.K. 2011. Anticancer biology of Azadirachtaindica L (neem): a mini review. Cancer Biology and Therapy, 12 (6), 467-476.
[17] Dhanya Kumar, N.M., Sidhu, P. 2011. The antimicrobial activity of AzadirachtaIndica, Glycyrrhizaglabrat, Cinnamumzeylanicum, Syzygiumaromaticum, Acacia nilotica on Streptococcus mutans and Enterococcus faecalis: An in vitro study. Endodontology, (23), 18-25.

[18] Doaa, E.D., Mohamed, S.G., Abdel, R.H., Farrag, Ahmed, E.A.M. 2011. Physiological and histological impact of Azadirachta indica (neem) leaves extract in a rat model of cisplatin-induced hepato and nephrotoxicity. Journal of Medicinal Plants Research, 5 (23), 5499-5506.

[19] Sivakumar, M., Tang, S.Y., Tan, K.W. 2014. Cavitation technology - a greener processing technique for the generation of pharmaceutical Nano emulsions. Ultrasonic Sonochemistry, 21 (6), 2069-2083.

[20] Efferth, T., Koch, E. 2011. Complex interactions between Phytochemicals. The Multi-Target Therapeutic concept of Phytotherapy. Current Drug Targets, 12 (1), 122-132. doi: 10.2174/138945011793591626.

[21] Govindachari, T.R., Suresh, G., Gopalakrishnan, G., Banumathy, B., Masilamani, S. 1998. Identification of antifungal compounds from the seed oil of Azadirachtaindica. Phytoparasitica, 26 (2), 109-116.

[22] Singh, N., Sastry, M.S. 1997. Antimicrobial activity of Neem oil. Indian Journal of Pharmacology, (13), 102-106.

[23] Biswas, K., Chattopadhyay, I., Banerjee, R.K., Bandyopadhyay, U. 2002. Biological activities and medicinal properties of neem (Azadirachtaindica) Current Science, 82 (11), 1336-1345

[24] Zong, A., Cao, H., Wang, F. 2012. Anticancer polysaccharides from natural resources: a review of recent research. Carbohydrate Polymers, 90 (4), 1395-1410.

[25] Efferth, T., Koch, E. 2011. Complex interactions between Phytochemicals. The Multi-Target Therapeutic concept of Phytotherapy.Current Drug Targets, 12 (1), 122-132.

[26] Dhanya Kumar, N.M., Sidhu, P. 2011. The antimicrobial activity of AzadirachtaIndica, Glycyrrhizaglabrat, Cinnamumzeylanicum, Syzygiumaromaticum, Acacia nilotica on Streptococcus mutans and Enterococcus faecalis: An in vitro study. Endodontology, 23, 18-25.

[27] Govindachari, T.R., Suresh, G., Gopalakrishnan, G., Banumathy, B., Masilamani, S. 1997. Identification of antifungal compounds from the seed oil of Azadirachtaindica. Phytoparasitica, 26 (2), 109-116.

[28] Lessa, F.C., Nogueira, I., Vargas Fda S., Spolidorio, D.M., Hebling, J., García-Godoy, F. 2010. Direct and transdentinal antibacterial activity of chlorhexidine. American Journal of Dentistry, 23: 255-9.

[29] Kher, A., Chaurasia, S.C. 1997. Antifungal activity of essential oils of three medical plants. Indian Drugs, (15), 41-42.

[30] Chhavi, S., Andrea, J.V., Payal, G., Taher, M.G., Tahir, A.R., Arif, H. 2014. Ethanolic Neem (Azadirachta indica) Leaf Extract Prevents Growth of MCF-7 and HeLa Cells and Potentiates the Therapeutic Index of Cisplatin. Journal of Oncology, Article ID 321754, 10 pages. 